\title{
REGULATION OF HEALTH WORKFORCE IN INDIA*
}

Regulação das profissões de saúde na Índia

${ }^{1}$ Public Health Foundation of India. New Delhi, India.

Correspondence: dharmesh.lal@phfi.org

Received: 06/03/2018. Reviewed: 09/13/2018. Approved: 09/20/2018.

\footnotetext{
*Original paper developed in the scope of the research "Institutional arrangements for mediation of the different institutions of regulation of health workforce in Brazil: legal-administrative itinerary of creation of new health professions and improvement of the Chamber of Regulation of Work in Health / MS", held by the Center of Study and Research in Health Law (Cepedisa) in 2018.
} 


\section{ABSTRACT}

Health workforce regulations are central to achieving health objectives, ensuring high and safe standards of healthcare. The health workforce regulation needs to ensure quality of education, infrastructure and continual maintenance of professionals' standards across all health professions. These measures also assure the public, other stakeholders, and practitioners that all the concerns about standards of the workforce will be addressed in transparent and consistent manner. Broadly the regulations consist of policy making, admission guidelines to the different health professional courses, defining and regulating education standards through controlling the qualifications and expertise of the faculty, teaching institutes required infrastructure, maintenance of a register, continuous upgradation and regular assessment of professional skills as well as monitoring the quackery-practice by unqualified people, investigating and dealing with problems in relation to the conduct, health or performance of registered practitioners. Healthcare in India is provided by a variety of groups with varying skill levels, across a range of systems of medicine both in the public and private sector and there are regulatory bodies for doctors, dentists, nurses and pharmacists. This paper presents India's Health Workforce Regulatory Model, identifying its main institutions and regulatory mechanisms.

\section{Keywords}

Health Workforce; Health Workforce Regulations; India Health System; Universal Health Coverage.

\section{RESUMO}

A regulação das profissões de saúde é crucial para atingir os objetivos nessa área, garantindo atendimento de alto padrão e segurança. As regulamentações sobre as profissões de saúde precisam assegurar a qualidade da educação, infraestrutura e a manutenção continua dos padrões profissionais em todas as profissões de saúde. Estas medidas também asseguram ao público, outras partes envolvidas, e profissionais de que todas as preocupações sobre os padrões dos profissionais serão tratadas de forma transparente e consistente. Em termos amplos as regulamentações consistem na criação de políticas, regras de admissão para os diferentes cursos para profissionais de saúde, definição e regulação dos padrões educativos através do controle das qualificações e expertise dos docentes, a infraestrutura exigida das instituições de estudo, a manutenção de registros, melhoramento contínuo e avaliação das habilidades profissionais, bem como o monitoramento das práticas integrativas e complementares de saúde por pessoas sem qualificação, investigando e resolvendo problemas relacionados à conduta, saúde ou desempenho dos profissionais registrados. Na Índia o atendimento médico é fornecido por uma variedade de quadros com variados níveis de conhecimento, em variados sistemas médicos, tanto no setor público quanto no privado e existem organismos normativos para médicos, odontologistas, enfermeiros e farmacêuticos. Este artigo apresenta o Modelo Normativo das Profissões de Saúde na Índia, identificando suas principais instituições e mecanismos normativos.

\section{Palavras-Chave}

Cobertura Universal de Saúde; Profissões de Saúde; Regulação das Profissões de Saúde; Sistema de Saúde da Índia. 


\section{Introduction}

As per Indian Census 2011, India has a population of 1.2 billion people and $31.16 \%$ of its population resides in urban areas. The governance of the country is carried out by a combination of various states, Union Territories, and Union government at the top, as the federal governance structure.

Constitutionally there is clear segregation of powers between Union and states' Governments to avoid the encroachment of each other functions, duties and responsibilities ${ }^{1}, 2$. Various roles and functions of Union and State Governments are written in three lists as detailed in the Seventh Schedule of the Indian Constitution: Union List, State List and Concurrent List. Largely, the Union List consists of subjects of national importance, such as Defense, Railways, External Affairs etc.; while the State list consists of subjects of local interest such as Police, Law \& Order, Water and Health, being the last one of the most important subjects of it, and the Concurrent list consists of subjects important to both Union and State governments, like Electricity, Economic \& Social Planning and, important for this paper, Medical Education.

Organizationally, for health governance there is Ministry of Health and Family Welfare (MOHFW) at national level, and similarly at every state level. As health is subject to the State, every state needs to provide budget for its own health delivery system including the infrastructure development, even though the Union government also provides additional budget from its own funds to states for various health programs, also known as National Health Programs (NHPs) and other centrally sponsored projects. The Union government through MOHFW also formulates policies like the National Health Policy, National Population Policy, operational guidelines, the Monitoring and Evaluation Plan and implementation strategies for NHPs and other such projects.

India's health services consist of public and private healthcare providers, charitable trusts, non-government organizations and informal practitioners, configuring a mixed healthcare system ${ }^{3},{ }^{4}$. However, most of the private healthcare providers, as in most countries, are concentrated in urban India, providing a second and third higher level of healthcare services. Public healthcare system that is totally run by governments has been developed in rural India uniformly, across the country with overarching District hospitals in each district headquarter. However, urban health

\footnotetext{
${ }_{1}^{1}$ INDIA. Ministry of Home Affairs. Census of India 2011. Rural urban distribution of population. Available at: <http://censusindia.gov.in/2011-prov-results/paper2/data_files/india/Rural_Urban_2011.pdf>. Accessed in: 14 May, 2018.

${ }^{2}$ INDIA. Governance \& Administration. Available at: <https://www.india.gov.in/topics/governanceadministration>. Accessed in: 17 May, 2018.

${ }^{3}$ SHEIKH, K.; SALIGRAM, P.S.; HORT, K. What explains regulatory failure? Analysing the architecture of health care regulation in two Indian states. Health Policy Plan, v. 30, n. 1, p. 39-55, Feb. 2015. 10.1093/heapol/czt095.

${ }^{4}$ RAO, M.; RAO, K.D.; SHIVA KUMAR, A.K.; CHATTERJEE, M.; SUNDARARAMAN, T. Human resources for health in India. Lancet, v. 377, n. 9765, p. 587-598, Jan. 2011. https://doi.org/10.1016/S0140-6736(10)61888-0.
} 
systems vary from city to city - depending upon the urban governance system and budget availability - and vary in structure, in contrast to their rural counterparts. The public healthcare infrastructure in rural areas has been developed as a three-tier system based and consists of Subcenter, Primary Health Centre and Community Health Centre ${ }^{5}$.

\section{India's Healthcare System}

\section{Subcenter}

A subcenter (SC) is established in a plain area for a population of 5,000 people, while for 3,000 people in hilly, difficult to reach, tribal areas. It is the most peripheral first contact point between the primary healthcare system and the community. Each SC is to be staffed by at least one auxiliary nurse midwife (ANM) / female health worker and one male health worker. SC provides services in relation to maternal and child health, family welfare, nutrition, immunization, diarrhea control, communicable diseases control programs and assigned tasks related to interpersonal communication in order to bring about behavioral change. MOHFW is providing $100 \%$ central assistance to all the SCs in the country since April 2002 in the form of salaries, rent and contingencies in addition to drugs and equipment.

\section{Primary Health Centre}

A Primary Health Centre (PHC) is established in a plain area for a population of 30,000 people, in hilly, difficult to reach, tribal areas for a population of 20,000. It is the first contact point between the village community and the medical officer. PHCs provide integrated curative and preventive healthcare to the rural population with emphasis on the preventive and promotion aspects of healthcare. The PHCs are established and maintained by the State Governments. As per minimum requirement, a PHC is to be staffed by a medical officer supported by 14 paramedical and other staff. It acts as a referral unit for five to six SCs and has four to six beds for inpatients.

\section{Community Health Centre}

Community Health Centers (CHCs) are established and maintained by the State Government in plain areas for a population of 120,000 people and in hilly, difficult to reach, tribal areas for a population of 80,000 people. As per minimum norms, a $\mathrm{CHC}$ is required to be staffed by four medical specialists, that is, surgeon, physician, gynecologist/obstetrician and pediatrician supported by 21 paramedical and other staff.

${ }^{5}$ INDIA. Ministry of Health \& Family Welfare. Indian Public Health Standards. Available at: <http://nhm.gov.in/ $\mathrm{nhm} / \mathrm{nrhm} /$ guidelines/indian-public-health-standards.html>. Accessed in: 17 May, 2018. 
It has 30 beds with an operation theater, X-ray, labor room and laboratory facilities as well as serving as a referral center for PHCs falling under its jurisdiction.

\section{District Hospital}

In the present 3-Tier structured level of care being provided by public health facilities, the District Hospital (DH) serves at a higher referral level. Its objective is to provide comprehensive healthcare services to the people in the district at an acceptable level of quality being responsive and sensitive to the needs of the people and referring centers. DH is the biggest secondary level public health facility in the district. There are $734 \mathrm{DHs}$ in the country, providing all specialties care to an average population of 1,5 million and is established and maintained by respective state government. A DH counts with 100 to 500 beds, depending upon the needs and the policy of the respective state government.

\section{National Rural Health Mission}

To strengthen the health systems and increase the health workforce, Government of India launched National Rural Health Mission in 2005, now converted to National Health Mission, aiming at the reduction of maternal and child mortality by increasing public expenditure in the health system, decentralization, structural changes, formalization of community participation in grass-root health planning, monitoring of health system delivery, increased demand for health services, reduction of inequity and creation of a village based frontline health worker named Accredited Social Health Activist (ASHA). Initially it was implemented in 18 states having poor health indicators and for the rural health infrastructure but due to its positive impacts now it is being run throughout the country including urban areas ${ }^{6}$, .

For all project activities the funds are released directly to the states as well as the guidelines on the manpower, performance and management by the MOHFW, under the central government.

\section{Health workforce management}

The health workforce is central to achieving health objectives ${ }^{8}$. A well performing health workforce should be able to perform as per the needs and expectations of the

\footnotetext{
${ }^{6}$ MOHANTY, S.K.; KASTOR, A. Out-of-pocket expenditure and catastrophic health spending on maternal care in public and private health centres in India: a comparative study of pre and post national health mission period. Health Econ Rev, v. 18, n. 7, p. 31. Sept. 2017. 10.1186/s13561-017-0167-1.

${ }^{7}$ DOKE, P.P. Decline and disparity in maternal mortality in pre- and post-national health mission period in India. Indian J Public Health, v. 60, n. 4, p. 294-297, Oct./Dec. 2016. Available at: <http://www.ijph.in/ temp/IndianJPublicHealth604294-7138633_194946.pdf>. 10.4103/0019-557X.195857.

${ }^{8}$ WORLD HEALTH ORGANIZATION. Key components of a well functioning health system. WHO, May 2010. Available at: <http://www.who.int/healthsystems/EN_HSSkeycomponents.pdf?ua=1>. Accessed in: 11 May, 2018.
} 
community and able to achieve the best possible outcomes under the existing circumstances and with the given resources with the appropriate management of the system ${ }^{9},{ }^{10}$.

Effectiveness of the health systems largely depends upon the quality of its workforce who are responsible for bringing the best in combination with other components like funding, technology, information and essential medicines ${ }^{11}$. Governments regulate health services and systems to improve their quality and health outcomes, ensure equity and access, protect the public, promote social cohesion and increase economic efficiency ${ }^{12}$.

The functioning of health systems, in any country, depends on the level of regulation of its workforce, as skilled and competent workforce is the key to the effective functioning of the health system. Regulation of the health workforce is aimed to ensure safe and high standards of healthcare to the community by improving the quality of the healthcare providers. Health workforce accountability provides a critical quality safeguard, while its neglect in scholarship and practice is unjustified ${ }^{13}$.

Health workforce regulations need to assure quality education, infrastructure and continual professional standards across all health functionaries. These measures also assure the public, other stakeholders, and practitioners that all concerns about standards of the workforce will be addressed in a transparent and consistent manner ${ }^{14}$. Health workforce regulations during the stage of medical education and professional conduct help in ensuring the quality of the health systems, better patient outcomes, increasing universal health coverage and cost-benefit to society ${ }^{15}$.

Broadly, the regulation consists of policy making, admission guidelines to the different health professional courses, defining and regulating education standards through controlling the qualifications \& expertise of the faculty, required infrastructure of the teaching institutes, maintaining a register, continual upgrades and regular assessment of professionals' skills as well as monitoring the quackery-practice by unqualified persons, investigating and dealing with problems in relation to the conduct, health or performance of registered practitioners.

\footnotetext{
${ }^{9}$ ANAND, S.; BÄRNIGHAUSEN, T. Health workers at the core of the health system: framework and research issues. Health Policy, v. 105, n. 2-3, p. 185-191, May 2012. 10.1016/j.healthpol.2011.10.012.

${ }^{10}$ TTANGCHAROENSATHIEN, V.; LIMWATTANANON, S.; SUPHANCHAIMAT, R.; PATCHARANARUMOL, W.; SAWAENGDEE, K.; PUTTHASRI, W. Health workforce contributions to health system development: a platform for universal health coverage. Bull World Health Organ, v. 91, n. 11, p. 874-880, Nov. 2013. 10.2471/BLT.13.120774.

${ }^{11}$ WORLD HEALTH ORGANIZATION - WTO. Monitoring the building blocks of health systems: a handbook of indicators and their measurement strategies. Available at: <http://www.who.int/healthinfo/systems/WHO_ MBHSS_2010_full_web.pdf $>$. Accessed in: 18 May, 2018.

${ }^{12}$ HARDING, A.; PREKER, A. (Eds.). Private participation in health services. Washington (DC): World Bank; 2003.

${ }^{13}$ HILL, T.E.; MARTELLI, P.F.; KUO, J.H. A case for revisiting peer review: Implications for professional selfregulation and quality improvement. PLoS One, v. 13, n. 6, June 28,2018 . Available at: <https://journals. plos.org/plosone/article?id=10.1371/journal.pone.0199961>. 10.1371/journal.pone.0199961.

${ }^{14}$ HARDING, A.; PREKER, A. (Eds.). op. cit. ORGANISATION FOR ECONOMIC CO-OPERATION AND DEVELOPMENT (OECD). Regulatory policy and the road to sustainable growth. Paris: OECD, 2010. Available at: <https:// www.oecd.org/regreform/policyconference/46270065.pdf>. Accessed in: 26 Oct., 2018.

${ }^{15}$ HARDING, A.; PREKER, A. (Eds.). op. cit.
} 
Regulation mechanisms should not be complicated so they do not hamper the swift functioning of the health systems and should have inbuilt flexibility to satisfy diverse healthcare needs ${ }^{16}$. Laxity in these regulations weakens the health systems affecting the progress towards Universal Health Coverage as well as increases risks to patient's lives and adverse outcomes. The structure of the regulatory framework should be free from the imposition of unnecessary financial and administrative burdens, and be flexible to allow for all kinds of health dynamics, and also integrated to adopt the changing needs of the health systems ${ }^{17}$.

Healthcare in India is provided by a variety of cadres with a mix of scientific, traditional and varying skill levels, across a range of systems of medicine both in the public and private sector. Table 1 describes the various terms, degrees that are typically granted along with the regulatory body, wherever such a body exists.

\section{Situation of the health workforce regulations in India}

India has varied health workforce teams, as evident from Table 1 above, but so far only five professional categories have regulatory bodies that are for doctors, dentists, nurses and pharmacists only. Presently the broad categories of paramedics, technicians for Lab, ECG, EEG, Radiographers etc. are not under any formal regulations for education or professional conduct.

These categories of professionals are produced by institutes having no set of laid down standards for infrastructure and faculties, affecting the quality of health delivery. Other big category of "informal practitioners" spread widely across the country, particularly in rural areas and hinterland with no formal professional qualifications, continue to deliver healthcare to millions of people with impunity. These practitioners usually practice as "Registered Medical Practitioners (RMPs)" to denote some sort of government approved body authorization to practice, although no such formal mechanism is in place.

Therefore, in India there are far more deregulated health workers than registered ones, affecting the quality of healthcare as well as jeopardizing the lives of millions $s^{18},{ }^{19}$. Even the council's records are not active in nature and mostly not updated for deaths, migration (within India and abroad), retirement, and for those that are not in active practice. This leads to inflation of the real count and duplication

\footnotetext{
${ }^{16}$ ORGANISATION FOR ECONOMIC CO-OPERATION AND DEVELOPMENT (OECD). OECD best practice principles for regulatory policy: the governance of regulators. Paris: OECD, 2014.

${ }^{17}$ Id. Ibid.

${ }^{18}$ MAY, C.; ROTH, K.; PANDA, P. Non-degree allopathic practitioners as first contact points for acute illness episodes: insights from a qualitative study in rural northern India. BMC Health Serv Res, n. 14:182, Apr. 2004. Available at: <https://bmchealthservres.biomedcentral.com/track/pdf/10.1186/1472-6963-14182>. https://doi.org/10.1186/1472-6963-14-182.

${ }^{19}$ SHARMA, C.; MUKHERJEE, K. Maternal healthcare providers in Uttar Pradesh, India; How to position informal practitioners within the system? J Family Reprod Health, v. 8, n. 4, p. 183-188, Dec. 2014.
} 
Table 1. Various health cadres in India and their regulations

\begin{tabular}{|c|c|c|}
\hline Cadre & $\begin{array}{l}\text { Regulatory } \\
\text { Body }\end{array}$ & Remarks \\
\hline $\begin{array}{l}\text { Allopathic Doctors: Having minimum degree of } \\
\text { bachelor of medicine and bachelor of surgery } \\
\text { with or without postgraduate qualifications (MD/ } \\
\text { MS) like the specialties of the doctor of medicine, } \\
\text { surgery, diplomas, DNB and super Medical and } \\
\text { Surgical specialization qualifications (Mch/DM). }\end{array}$ & $\begin{array}{l}\text { Medical } \\
\text { Council of } \\
\text { India }(\mathrm{MCl})\end{array}$ & $\begin{array}{l}\text { All India Institute of Medical } \\
\text { Sciences (AlIMS) and National } \\
\text { Board of Examinations } \\
\text { functions independently of } \mathrm{MCl} \text {. }\end{array}$ \\
\hline $\begin{array}{l}\text { AYUSH Doctors: Practitioners of Ayurveda, } \\
\text { Homeopathy, Unani, Sidha and SowaRigpa. } \\
\text { This group holds minimum bachelors and/ } \\
\text { or postgraduate degrees in one of the above } \\
\text { traditional medicine systems. }\end{array}$ & $\begin{array}{l}\text { Central Council } \\
\text { for Indian } \\
\text { Medicine or } \\
\text { the Central } \\
\text { Council for } \\
\text { Homeopathy. }\end{array}$ & \\
\hline $\begin{array}{l}\text { Dentists: Having minimum bachelor degree (BDS) } \\
\text { and or master degree (MDS). }\end{array}$ & $\begin{array}{l}\text { Dental Council } \\
\text { of India. }\end{array}$ & \\
\hline $\begin{array}{l}\text { Nurses: Include (i) auxiliary nurses and midwives. } \\
\text { This group receives a (i) two year diploma in } \\
\text { auxiliary nursing and midwifery; (ii) three and a } \\
\text { half year diploma in general nursing and midwifery } \\
\text { (GNM); (iii) four year bachelors degree (BSc) which } \\
\text { may be followed by (iv) a two to three year post- } \\
\text { graduate degree (MSc) / MPhil and PhD programs. }\end{array}$ & $\begin{array}{l}\text { Nursing } \\
\text { Council of } \\
\text { India }\end{array}$ & \\
\hline
\end{tabular}

\section{Pharmacists: With a diploma, bachelor or master} degree in pharmacy.

\section{Pharmacy}

council of India

$\begin{array}{ll}\begin{array}{l}\text { Allied and } \\ \text { healthcare }\end{array} & \begin{array}{l}\text { Besides physiotherapists, } \\ \text { nutritionists, radiological }\end{array} \\ \text { professional's } & \text { service providers and other } \\ \text { central council } & \text { over } 50 \text { related healthcare } \\ \text { (proposed) } & \text { professionals would be } \\ & \text { part of the proposed council. } \\ & \text { The council would set } \\ & \text { standards for their education } \\ & \text { and practices. }\end{array}$

Technicians such as laboratory

None May come under the proposed council above

technician, electrocardiogram technician, electroencephalography technician; dental technician and audiometrist

\begin{tabular}{lll}
\hline Radiographer & None & $\begin{array}{l}\text { To come under the proposed } \\
\text { council above }\end{array}$ \\
\hline Dietitian & None & \\
\hline Dental aAssistant & None & \\
\hline Ophthalmic aAssistant & None \\
\hline
\end{tabular}


Continuation

\begin{tabular}{lll}
\hline Cadre & $\begin{array}{c}\text { Regulatory } \\
\text { Body }\end{array}$ & \multicolumn{1}{c}{ Remarks } \\
\hline $\begin{array}{l}\text { Community Health Workers: Include terms such as } \\
\text { health assistants and health educators.. }\end{array}$ & None & $\begin{array}{l}\text { Health assistant basic duties are } \\
\text { to assist, supervise, and monitor } \\
\text { the activities of the health }\end{array}$ \\
& & $\begin{array}{l}\text { workers under their supervision } \\
\text { in the field, while health } \\
\text { educators provide information, } \\
\end{array}$ \\
& & education and communication \\
& & to the community \\
\hline
\end{tabular}

Accredited Social Health Activists (ASHAs):

None

established under National Rural Health Mission,

are a voluntary female workers selected from the

village itself and paid incentive against the services

rendered. They are the first contact between the

community and the public health system.

Registered medical practitioners: this group None
consists of practitioners with no formal medical
qualification and training.

Traditional healers: a person who uses None

long-established methods passed down from

one healer to another like mysticism, chants to

treat a person suffering from various illnesses,

many of which have psychological underpinnings.

Sources: Medical Council of India; Dental Council of India; India Nursing Council; Pharmacy Council of India; Central Council of Indian Medicine.

Author's elaboration.

of figures. Information on the health workforce is not being systematically collated and analyzed, except for allopathic doctors. Then the regulation of skills and expertise of the health workforce after registration is almost non-existent unlike other countries such as United States, United Kingdom, Australia, and New Zealand etc. where these professionals are submitted to regular skills assessment. In some of the states medical councils, especially those of Delhi, Maharashtra and other major cities, registrations are only issued for a stipulated period of time (typically five years) and thereafter they need to be renewed and this is only an administrative procedure, not essentially a revalidation.

Regulations in India are established by the policies made by the government, both at the central and states levels, for all types of workforce consisting of doctors, dentists, nurses, and paramedical staff, although these policies are set and directed by central government. Policies are backed by legally tenable notifications by these governments which are backed by parliament and legislative assemblies' approvals and act as referrals for enforcing the regulatory standards. Different regulatory 
agencies with statutory backing are in formation for different categories of health workers, as there are different bodies for doctors (Medical Council of India), Dentists (Dental Council of India), Nurses (Nursing Council of India), AYUSH (Central Council of Indian Medicine) and Homoeopaths (Homoeopathic Council of India) although a unified agency is in the offing. Different regulatory bodies have wide variety in their levels of functioning and therefore wide differences in ensuring the health workforce quality standards.

\section{Medical Council of India}

The Medical council of India (MCI) is the statutory regulating body for allopathy established by MOHFW, Government of India, under the Indian Medical Council Act, 1933, which has been amended number of times and has been modified in 1964, 1993 and 2001. A major mandate of MCI is to establish uniform standards and regulate the medical education at all levels from undergraduate, postgraduate to the higher specialty levels besides recognition of medical qualifications in India and abroad for allopathic doctors.

All the regulations formulated by this body are applicable to the medical institutions imparting the undergraduate, and or postgraduate and super specialization degree and diploma courses of medicine and surgery, irrespective of Central, state or private management. But institutes like All India Institute of Medical Sciences (AIIMS) and National Board of Examinations are exceptions and function completely under their own rules and regulations.

To ensure the quality of medical education, MCI has set objectives of: (i) Maintenance of uniform standards of medical education, both undergraduate and postgraduate; (ii) recommendation for recognition/derecognition of medical qualifications of institutions from India or foreign countries; (iii) permanent registration/provisional registration of doctors with recognized medical qualifications; (iv) reciprocity with foreign countries in the matter of mutual recognition of medical qualifications; (v) screening test for Indian nationals who are graduates from foreign medical institutions; (vi) maintenance of Indian Medical Register (vii) issue of good standing certificates; (viii) accreditation of Medical Colleges; (ix) maintenance of Faculty Database; (x) ensuring medical ethics and discipline among doctors.

\subsection{Maintenance of uniform standards of medical education, both undergraduate and postgraduate}

MCI formulate the curriculum for various undergraduate and postgraduate courses, which are to be followed by all the medical colleges included within its ambit. Graduate medical curriculum is oriented towards training students to undertake the responsibilities of a physician of first contact who is capable of looking after the preventive, fostering, curative \& rehabilitative aspects of medicine. There 
is a mix of different learning methods in the form of lectures, hands on experience like exposure to field practicing areas and training during internship phase with a defined period for each component of the course. Emphasis is not only on diseases and hospitals but also on overall health and community. Various committees are formed whenever curriculum revision is to be done. Students' examination process with all the details of theory and practice including the appointment of internal and external examiners (other than the institute teaching staff) is done by the affiliated university strictly as per the MCI guidelines as every medical institute is compulsorily required to affiliate to a recognized university for awarding degrees.

\subsection{Recommendations for recognition / derecognition of qualifications of medical institutions of India or foreign countries}

MCI has a system in place to regularly monitor the quality of medical institutes in India, against predefined standards in terms of manpower for quantity, qualifications, experience etc., both for faculty and non-faculty posts, physical infrastructure for each department with measurements for specified areas, equipment in each department and attachment of tertiary level hospital in same premises.

Medical colleges/institutes are to regularly share the information with the MCI as per the set formats, with strict focus on infrastructure facilities, number and kind of faculty members including the student teacher ratio, attached lab and hospital facilities etc. and also, compulsorily, on their websites, accessible for free public view. Upon the basis of parameters like these, the recognition status is decided and any institute not able to meet these standards is liable to be derecognized. In addition, the MCI has a pool of "Medical Inspectors" who are senior faculty members selected from various medical colleges, randomly visit some of the medical colleges for surprise checks, to ascertain the veracity of the information they supplied.

Besides these measures, a new medical institute is allowed to start the new courses only after fulfilling all the criteria as certified by Medical Inspectors after physical verifications. These inspections are done using predefined checklists, which are explicit and transparent and are all available on the website and separately available in downloadable format for: (i) starting a new Medical College; (ii) minimum requirements for 50 admissions; (iii) minimum requirements for 100 admissions; (iv) minimum requirements for 150 admissions; (v) minimum requirements for 200 admissions; (vii) minimum requirements for 250 admissions.

All the medical colleges are also visited every three to five years for physical verification of the standards, for renewal of the recognition, and also prior to start any new course and/ or increasing the number of the admissions of students. MCI also decides on a country-to-country basis the recognition of qualifications granted 
by other countries, based on the curriculum, norms and other standards vis a vis those followed in India.

\subsection{Qualifications Registration}

The MCI and its various state subsidiaries are entrusted to register the medical qualifications in individual names for ensuring that only qualified allopathic medical practitioners are allowed to practice. As the undergraduate medical course consists of mandatory one-year internship, after completion of the theoretical component, a provisional registration is also provided only to allow the completion of internship.

A unique registration number is issued which is compulsory for practicing medicine and needed also for all other assignments including teaching in medical colleges. Registration is compulsory after acquiring every qualification, which is permanent except in certain states like Delhi, Maharastra where it is to be renewed every five years. Under the code of ethics Medical doctors can only practice and become faculty members as per the registered qualifications and specialty, while bachelor of medicine and bachelor of surgery can only work in general practice. Registration details of every doctor is available on the MCI website also for verification purposes. Breach of these guidelines is liable to be punished both by MCI and the judiciary.

\subsection{Reciprocity with foreign countries in the matter of mutual medical qualifications recognition}

Provision is made with a specific country to recognize qualifications level-bylevel taking into consideration their robustness and credibility for reciprocity. Some of these countries are Australia, Canada, New Zealand and the United Kingdom and agreements are reached separately with countries.

\subsection{Screening test for graduates from foreign medical institutions}

Any State Medical Council (SMC) and or the MCI can register any Indian student with foreign medical qualifications only after he/she appears and passes the Foreign Medical Graduate Examination (FMGE) conducted by the National Board of Examinations (NBE), under MOHFW, which is a statutory requirement as per section 13(4A) of the IMC Act, 1956 amended in 2002. It is provided that a person seeking provisional or permanent registration shall not have to qualify the Screening Test if he/she holds an under graduate medical qualification from Australia, Canada, New Zealand, United Kingdom and United States of America and the holder thereof has also been awarded a post graduate medical qualification in those countries and has been recognized for enrolment as medical practitioner in that country. 


\subsection{Maintenance of Indian Medical Register}

One of the important strategies to regulate the health workforce, this register is now available on the MCI website containing details such as name, date of birth and qualifications with graduation year. A separate link is also provided with details on teaching faculty with specific colleges and specialty as faculty are allowed to teach only in one particular medical institute. This register also has a link to show blacklisted doctors due to misconduct and prohibited from practicing medicine.

\subsection{Issue of good standing certificates}

This certificate is issued by MCI and valid for six months only. Such certificate is issued based on the medical practitioner past conduct and is used to keep track of professional ethics of registered members.

\subsection{Accreditation of Medical Colleges}

Keeping under check the infrastructure of the medical colleges according to laid norms is crucial to maintain medical educational standards and the quality of the health workforce. This is done by Medical Inspectors through the method of physical verification, using the checklists on manpower, equipment, physical infrastructure, lab facilities, attached hospital infrastructure etc.

\subsection{Maintenance of Faculty Database}

This is a list of faculty members attached to a specific medical college for each specific subject and is available on the MCI website. Therefore, a particular faculty member is authorized to teach full time a subject matching the registered postgraduate qualification and experience, only at a medical college, to ensure the quality of medical education.

\section{Dental Council of India}

The Dental Council of India is a statutory body constituted on April 121949 under an Act of Parliament, the Dentists Act, 1948 (XVI of 1948). Amendments have been made in the act to restrict the proliferation of dental colleges, increase of the number of seats in any of the courses and the start of new higher courses without the prior permission of the Central Government (MOHFW).

The Council is financed mainly by grants from the Government of India, MOHFW, the other source of income is $1 / 4^{\text {th }}$ share of fees received every year by various State Dental Councils under section 53 of the Dentists Act, Inspection fees from the various Dental Institutions charged for Inspecting under Section 15 of the Dentists Act, 1948, and application fee paid to the organization on permissions for 
applications to set up new Dental College, opening of higher Courses of study and increase of admission capacity in Dental Colleges, under section 10A of the Dentists Act, 1948 as amended by the Dentists (Amendment) Act, 1993.

Aiming at the Maintenance of Dental Education uniform standards - both at undergraduate and postgraduate levels - it undertakes: (i) inspections/visitations of Dental Colleges to grant permissions to start functioning, to increase the number of seats, start new postgraduate courses (as per provisions of section 10A of the Act); (ii) prescription of examinations standards and other requirements to be satisfied to secure qualifications recognition under the Act; (iii) prescription of standard curricula for the training of dentists, dental hygienists, dental mechanics, and the conditions for such training.

These guidelines are achieved through the uniformity of curriculum standards regarding technical and clinical requirements, standards of examinations; the affiliation of every dental college to a university, and supervision of all dental institutions to ensure that they maintain professional dentistry prescribed standards and regulations.

\subsection{Functions}

The council is composed of 6 constituencies representing Central Government, State Government, universities, dental colleges, $\mathrm{MCI}$ and the private dentistry practitioners. The director general of Health Services is ex-officio member - both of the Executive Committee and General Body. The Council elects internally the president, vice-president and members of the executive committee.

The elected President and vice-president are ex-officio the executive committee chairman and vice chairman. The executive committee is the governing body of this organization, which deals with all council procedural, financial and day-today activities and affairs. DCI functioning is quite similar to MCI as described, in ensuring the standards of the dental health workforce in the country.

\section{Indian Nursing Council}

The Indian Nursing Council constituted by the Central Government under section 3(1) of the Indian Nursing Council Act, 1947 of parliament is an Autonomous Body under the Government of India, MOHFW.

Basic aims, objectives and functions of the Indian Nursing Council are: (i) to establish and monitor a uniform standard of nursing education for nurses midwives, auxiliary nurse-midwives and health visitors by doing inspection of the institutions; (ii) to recognize the qualifications under section 10(2) (4) of the Indian Nursing Council Act, 1947 for the purpose of registration and employment in India and 
abroad; (iii) to give approval for registration of Indian and Foreign Nurses possessing foreign qualification under section 11(2)(a) of the Indian Nursing Council Act, 1947; (iv) to prescribe the syllabus \& regulations for Nursing programs; (v) power to withdraw the recognition of qualification under section 14 of the Act in case the institution fails to maintain its standards under such section (l) (b) and recognized by a State Council for the training of nurses, midwives, auxiliary nurse midwives or health visitors do not satisfy the requirements of the Council; (vi) to advise the State Nursing Councils, examining boards, State Governments and Central Government in various important items regarding nursing education in the country.

For every program the objectives, eligibility criteria, school infrastructure requirement and intended competencies to be accomplished by students at the end of the course, are defined and published for ready reference and statutory interpretations.

\subsection{Functions}

Nursing Council of India is governed by a president, supported by a vice president, secretary, assistant secretary and other staff for ensuring the implementation of its standards throughout the country. The executive committee deliberates on issues related to the maintenance of nursing program standards.

Nursing Education Committee is concerned mainly with nursing education and related policy matters; the Equivalence committee deliberates on the issues of recognition of foreign qualifications, which is essential for registration purposes under section 11(2)(a) or (b) of the Indian Nursing Council Act,1947 as amended.

\section{Regulation of the AYUSH health workforce}

AYUSH is the common name for different systems of medicine.

(e) Ayurveda: A form of alternative medicine that is India's traditional system and seeks to treat and integrate body, mind, and spirit using a comprehensive holistic approach especially by emphasizing diet, herbal remedies, exercise, meditation, breathing, and physical therapy.

(f) Yoga: A discipline to improve or develop one's inherent power in a balanced manner. It offers the means to attain complete self-realization. The literal meaning of the Sanskrit word Yoga is "Yoke". Yoga can therefore be defined as a means of uniting the individual spirit with the universal spirit of God.

(g) Naturopathy: Art and science of healthy living and a drugless system of healing based on well-founded philosophy.

(h) Unani: As the name indicates, Unani system originated in Greece. Hippocrates laid the foundations of Unani. The system owes its present form to the Arabs who not only saved much of the Greek literature by rendering it into Arabic but 
also enriched the medicine of their days with their own contributions. In this process they made extensive use of sciences like Physics, Chemistry, Botany, Anatomy, Physiology, Pathology, Therapeutics and Surgery.

(i) Siddha: One of the oldest systems of medicine in India. The term Siddha means achievements. Siddhars were saintly people who achieved results in medicine. Eighteen Siddhars were said to have contributed towards the development of this medical system. The Siddha System is largely therapeutic in nature.

(j) Homoeopathy: System of alternative medicine based on doctrine of like cures like, a claim that a substance that causes the symptoms of a disease in healthy people would cure similar symptoms in sick people.

(k) Sowa Rigpa: Commonly known as the Tibetan system of medicine is one of the oldest, living and well documented medical traditions of the world. Originated in Tibet is popularly practiced in India, Nepal, Bhutan, Mongolia and Russia. Most of the theory and practice of Sowa-Rigpa is similar to "Ayurveda".

The Department of Indian Systems of Medicine and Homoeopathy (ISM\&H) was created in March, 1995 and re-named as Department of Ayurveda, Yoga \& Naturopathy, Unani, Siddha and Homoeopathy (AYUSH) in November, 2003, with the vision of providing focused attention to the development of education \& research in Ayurveda, Yoga \& Naturopathy, Unani, Siddha and Homoeopathy systems. The Department continued to lay emphasis on upgrading AYUSH educational standards, quality control, standardization of drugs, improving the availability of medicinal plants material, research and development and raising awareness about the efficacy of the systems domestically and internationally.

Various strategies to achieve the improvement of the health workforce regulations were set, such as: (i) upgrade the educational standards in the Indian Systems of Medicine and Homoeopathy colleges in the country; (ii) ensure availability of quality education and training to AYUSH doctors/scientists/teachers; (iii) ensure availability of quality paramedical, pharmacy, nursing education and training; (iv) provide opportunities for quality AYUSH education throughout the country; (v) empower AYUSH professionals with improved skills and attitudes and; (vi) promote building capacity of institutions, centers of excellence (COE), national institutes etc.

\section{Central Council of Indian Medicine (CCIM)}

CCIM is a statutory body, under the AYUSH Department and mainly responsible for regulating AYUSH education and workforce in the country. Constituted under the Indian Medicine Central Council Act, 1970 it has the following objectives: (i) rescribe the minimum standards of education in Indian Systems of Medicine viz. Ayurveda, Siddha, UnaniTib and Sowa Rigpa; (ii) advise Central Government in matters related to recognition (inclusion/withdrawal) of medical 
qualifications in/from Second Schedule of Indian Medicine Central Council Act, 1970; (iii) maintain a Central Register of Indian Medicine and revise the register from time to time, prescribe standards of professional conduct, etiquette and code of ethics to be observed by practitioners; (iv) consider and furnish recommendations to the Government of India on the proposals received by them from various institutions for the establishment of new colleges of Indian Systems of Medicine; (v) increase intake capacity in under-graduate, post-graduate degree and diploma courses, and start new post-graduate courses or additional subjects.

Preparation and maintenance of Central Register of Indian Medicine is one of the main objectives of the Central Council. As per provisions of IMCC Act, 1970, the Central Council is maintaining a Central Register in the prescribed manner, containing the names of people enrolled on any State Registers of Indian Medicine and who possess any of the recognized medical qualifications included in the Indian Medicine Central Council Act schedules, 1970. The maintenance and updating of the Central Register of Indian Medicine is a continuous process.

Since its establishment in 1971, the Central Council has been framing and implementing various regulations including the Curricula and Syllabi in Indian Systems of Medicine viz. Ayurveda, Siddha, UnaniTib at undergraduate and post-graduate level. CCIM has prescribed regulations for under-graduate and post-graduate courses of Ayurveda, Siddha and UnaniTib considering that after completion of education, students would become scholars with deep basis and profound scientific knowledge of the fundamentals of the respective systems.

Under the Ayurveda system, the students are trained as Teachers Research scholars, Kayachkitsak (physicians) and ShalyaChikitsak (Surgeons). CCIM has prescribed various regulations approved by the Government of India such as: (i) Central Council of Indian Medicine Regulations (election of president and vice-president), 1971; (ii) Central Council of Indian Medicine Regulations (general), 1976 amended in 2012; (iii) Central Council of Indian Medicine Regulations (inspectors and visitors), 1977; (iv) Central Council of Indian Medicine Regulations (Central Register of Indian Medicine), 1979; (v) Practitioners of Indian Medicine Regulation (standards of professional conduct, etiquette and code of ethics), 1982; (vi) Indian Medicine Central Council Amendment Regulations (minimum standards required from Ayurveda colleges and attached hospitals), 2016; (vii) Indian Medicine Central Council Amendment Regulation (minimum standards of education in Indian Medicine), 2016; (vii) Ayurveda under-graduated regulations, Indian Medicine Central Council Amendment Regulation (requirement of minimum standards for under-graduate Unani colleges and attached hospital), 2016; (viii) Indian Medicine Central Council Amendment Regulation for Kamil-e-tib-o-jarahat (bachelor of Unani medicine \& surgery) course, 2016, Indian Medicine Central Council Amendment Regulation (requirement of minimum standards for under-graduate Siddha colleges and attached hospitals), 
2016; (ix) Indian Medicine Central Council Regulations (minimum standards for education in Indian Medicine), 2016 (Siddha under-graduated regulations); (x) Indian Medicine Central Council Amendment Regulations(post graduate Ayurveda education), 2016; (xi) Indian Medicine Central Council Amendment Regulations (post graduate Unani Medical education), 2016; (xii) Indian Medicine Central Council Amendment Regulations (post graduate Siddha Education), 2016, establishment of New Medical College, opening of new higher course of training and increase of admission capacity by a Medical College Regulations, 2003; (xiii) Indian Medicine College Council Regulations (permission to existing medical colleges), 2006; (xiv) Indian Medicine Central Council Regulation, 2010, and amended in 2013 (post graduate diploma course).

\section{Pharmacy Council of India}

Pharmacy education and the pharmaceutical profession in India, up to graduate level, is regulated by the Pharmacy Council of India (PCI), a statutory body governed by the provisions of the Pharmacy Act, 1948 passed by the Parliament with the objective of Regulation of Pharmacy Education in the country providing registration for pharmacists under the Pharmacy Act and Profession and Practice of Pharmacy.

To maintain the standards and enforce regulations under the act, PCI performs various duties such as: (i) prescribe minimum standard of education required for qualifying as a pharmacist; (ii) framing of education regulations prescribing the conditions to be fulfilled by the institutions seeking approval of the PCI for imparting education in pharmacy; (iii) to ensure uniform implementation of the educational standards throughout the country, inspection of pharmacy institutions seeking approval under the Pharmacy Act and verification of the compliance to the prescribed norms; (iv) approve the course of study and examination for pharmacists i.e. approval of the academic training institutions providing pharmacy courses; (v) withdraw approval from approved courses of study or examinations, which are not in conformity with the educational standards prescribed by the PCI; (vi) to approve qualifications granted outside the territories to which the Pharmacy Act extends i.e. the approval of foreign qualifications and; (vii) to maintain Central Register of Pharmacists.

\section{Unregulated health workforce professions}

As is evident from Table 1, the large number of the health workforce in India for professions like Physiotherapist, paramedical workers, frontline health workers and unqualified medical practitioners do not have a regulatory body like those described for doctors, dentists, nurses and pharmacists. 
Unqualified medical practitioners (UMPs) are treated by the law as illegal, but due to paucity of monitoring infrastructure and their presence in rural areas, it is not possible to completely stop them from practicing, and hence, prevent dangers to the lives of people seeking care from them. UMPs are the largest number of health providers in the country and far more in numbers than qualified registered doctors ${ }^{20}$.

The other categories mentioned do not have any regulatory bodies and are eligible to work only after undergoing some minimum prescribed training, but enforcement of such regulation is almost non-existent. But for working in governmental health facilities these categories of staff need to have the prescribed minimum qualifications and experience as applicable.

Recruitment is done only after the combination of face-to-face interview and/ or written test to ensure they have minimum qualifications and experience.

\section{Conclusions}

India has in place formal bodies for workforce regulation for doctors, dentists, nurses and pharmacists so far. These are statutory bodies and therefore bear legal sanctions to implement its various provisions.

MCI is the largest of these bodies and regulates the work of allopathic doctors, but their function is still to address the issue of up to date maintenance of members' registers, as these registers are not regularly updated with changes on account of deaths, migration, retirement and inactive members.

Another major issue is the lack of regular assessments on a permanent basis of the professionals' qualifications and skills, which affects the upgrading of skills and competencies after acquiring the registration. Recently though, a bill (National Medical Commission [NMC] Bill 2017) ${ }^{21}$ was introduced in the parliament to address this lacuna particularly for allopathic doctors.

To address the large variation in medical education in India across various states, public and private sector, has been suggested the provision of a National Medical Licentiate Examination under the NMC Bill 2017, presently under consideration of the parliament, before offering the registration to allopathic doctors, and, in other streams, for AYUSH, dentists and Nurses. The wide variations in medical education standards across the country and the existing provisions require great restructuring to bring uniformity to the final product.

\footnotetext{
${ }^{20}$ ANAND, S.; FAN, V. The health workforce in India. Human resources for Health Observer Series No. 16. Geneva: WHO, 2016 Available at: <http://www.who.int/hrh/resources/16058health_workforce_India. pdf>. Accessed in: 26 Oct., 2018.

${ }^{21}$ INDIA. Ministry of Health \& Family Welfare. FAQs on National Medical Commission Bill, 2017. Available at: <https:// mohfw.gov.in/newshighlights/faqs-national-medical-commission-bill-2017>. Accessed in: 27 May, 2018.
} 
Councils are autonomous in the day to day functioning and can deliberate strictly under the given mandate, but changes at policy level can be effected only by Indian parliament and central government to ensure their work is regulated and to create laws and rules in the best interest of the people. Importantly, the license of a registered health functionary is liable to be terminated and the individual concerned is liable to judicial review and punishment if found to have broken the rules of the respective council.

For professions like Physiotherapist, Lab technician, Radiographer and more than 50 such categories, there is a movement to bring them under some sort of regulation by establishing a separate council named Allied and Healthcare Professional's Central Council. Many of the professions as mentioned in Table 1 do not have an existing formal regulation structure and these categories of the health workforce continue to thrive as such, affecting the quality of health delivery and even jeopardizing the lives of millions of citizens as do UMPs and Traditional healers.

Surprisingly for these categories of practitioners a system of monitoring is almost non-existent and still no such plan is in the offing for developing one. A developing country like India suffers from the absence of credible and readily available information on the health workforce, affecting the work of health planners and researchers. And the situation gets further worsened when millions of health professionals do not have any registration mechanism.

The implementation of all the necessary changes requires the formal establishment of statutory bodies like those existing for doctors and nurses, and the maintenance of up to date registers for all categories of workers. Another important change required is having information available of the registered workforce at the lowest possible administrative levels, and not just at state level as it is at present. Information at district level and further below will tremendously help in planning health services accordingly and help achieve universal health coverage.

\section{References}

ANAND, S.; BÄRNIGHAUSEN, T. Health workers at the core of the health system: framework and research issues. Health Policy, v. 105, n. 2-3, p. 185-191, May 2012. 10.1016/j. healthpol.2011.10.012.

; FAN, V. The health workforce in India. Human resources for Health Observer Series No. 16. Geneva: WHO, 2016 Available at: <http://www.who.int/hrh/resources/16058health_ workforce_India.pdf $>$. Accessed in: 26 Oct., 2018.

DOKE, P.P. Decline and disparity in maternal mortality in pre- and post-national health mission period in India. Indian J Public Health, v. 60, n. 4, p. 294-297, Oct./Dec. 2016. Available at: <http://www.ijph.in/temp/IndianJPublicHealth604294-7138633_194946.pdf >. 10.4103/0019-557X.195857. 
HARDING, A.; PREKER, A. (Eds.). Private participation in health services. Washington (DC): World Bank; 2003.

HILL, T.E.; MARTELLI, P.F.; KUO, J.H. A case for revisiting peer review: Implications for professional self-regulation and quality improvement. PLoS One, v. 13, n. 6, June 28, 2018. Available at: <https://journals.plos.org/plosone/article?id=10.1371/journal.pone.0199961>. 10.1371/journal.pone.0199961.

INDIA. Governance \& Administration. Available at: <https://www.india.gov.in/topics/ governance-administration>. Accessed in: 17 May, 2018.

. Ministry of Health \& Family Welfare. FAQs on National Medical Commission Bill, 2017. Available at: $<$ https://mohfw.gov.in/newshighlights/faqs-national-medical-commissionbill-2017>. Accessed in: 27 May, 2018.

. Ministry of Health \& Family Welfare. Indian Public Health Standards. Available at: $<$ http://nhm.gov.in/nhm/nrhm/guidelines/indian-public-health-standards.html $>$. Accessed in: 17 May, 2018.

. Ministry of Home Affairs. Census of India 2011. Rural urban distribution of population. Available at: <http://censusindia.gov.in/2011-prov-results/paper2/data_files/ india/Rural_Urban_2011.pdf>. Accessed in: 14 May, 2018.

MAY, C.; ROTH, K.; PANDA, P. Non-degree allopathic practitioners as first contact points for acute illness episodes: insights from a qualitative study in rural northern India. BMC Health Serv Res, n. 14:182, Apr. 2004. Available at: <https://bmchealthservres.biomedcentral.com/ track/pdf/10.1186/1472-6963-14-182>. https://doi.org/10.1186/1472-6963-14-182.

MOHANTY, S.K.; KASTOR, A. Out-of-pocket expenditure and catastrophic health spending on maternal care in public and private health centres in India: a comparative study of pre and post national health mission period. Health Econ Rev, v. 18, n. 7, p. 31. Sept. 2017. 10.1186/ s13561-017-0167-1.

ORGANISATION FOR ECONOMIC CO-OPERATION AND DEVELOPMENT (OECD). OECD best practice principles for regulatory policy: the governance of regulators. Paris: OECD, 2014. Accessed in: 26 Oct., 2018.

Regulatory policy and the road to sustainable growth. Paris: OECD, 2010. Available at: <https://www.oecd.org/regreform/policyconference/46270065.pdf >. Accessed in: 26 Oct., 2018.

RAO, M.; RAO, K.D.; SHIVA KUMAR, A.K.; CHATTERJEE, M.; SUNDARARAMAN, T. Human resources for health in India. Lancet, v. 377, n. 9765, p. 587-598, Jan. 2011. https:// doi.org/10.1016/S0140-6736(10)61888-0.

SHARMA, C.; MUKHERJEE, K. Maternal healthcare providers in Uttar Pradesh, India; How to position informal practitioners within the system? J Family Reprod Health, v. 8, n. 4, p. 183-188, Dec. 2014. 
SHEIKH, K.; SALIGRAM, P.S.; HORT, K. What explains regulatory failure? Analysing the architecture of health care regulation in two Indian states. Health Policy Plan, v. 30, n. 1, p. 39-55, Feb. 2015. 10.1093/heapol/czt095.

TANGCHAROENSATHIEN, V.; LIMWATTANANON, S.; SUPHANCHAIMAT, R.; PATCHARANARUMOL, W.; SAWAENGDEE, K.; PUTTHASRI, W. Health workforce contributions to health system development: a platform for universal health coverage. Bull World Health Organ, v. 91, n. 11, p. 874-880, Nov. 2013. 10.2471/BLT.13.120774.

WORLD HEALTH ORGANIZATION - WTO. Monitoring the building blocks of health systems: a handbook of indicators and their measurement strategies. Available at: $<$ http://www.who. int/healthinfo/systems/WHO_MBHSS_2010_full_web.pdf>. Accessed in: 18 May 2018.

Key components of a well functioning health system. WHO, May 2010. Available at: <http://www.who.int/healthsystems/EN_HSSkeycomponents.pdf?ua=1>. Accessed in: 11 May, 2018.

Dharmesh K. Lal - DNB; MD; DHA; MBBS. National Capacity Building and Quality Assurance Expert and Program Lead at Public Health Foundation of India. New Delhi, India. E-mail: dharmesh.lal@phfi.orgs 